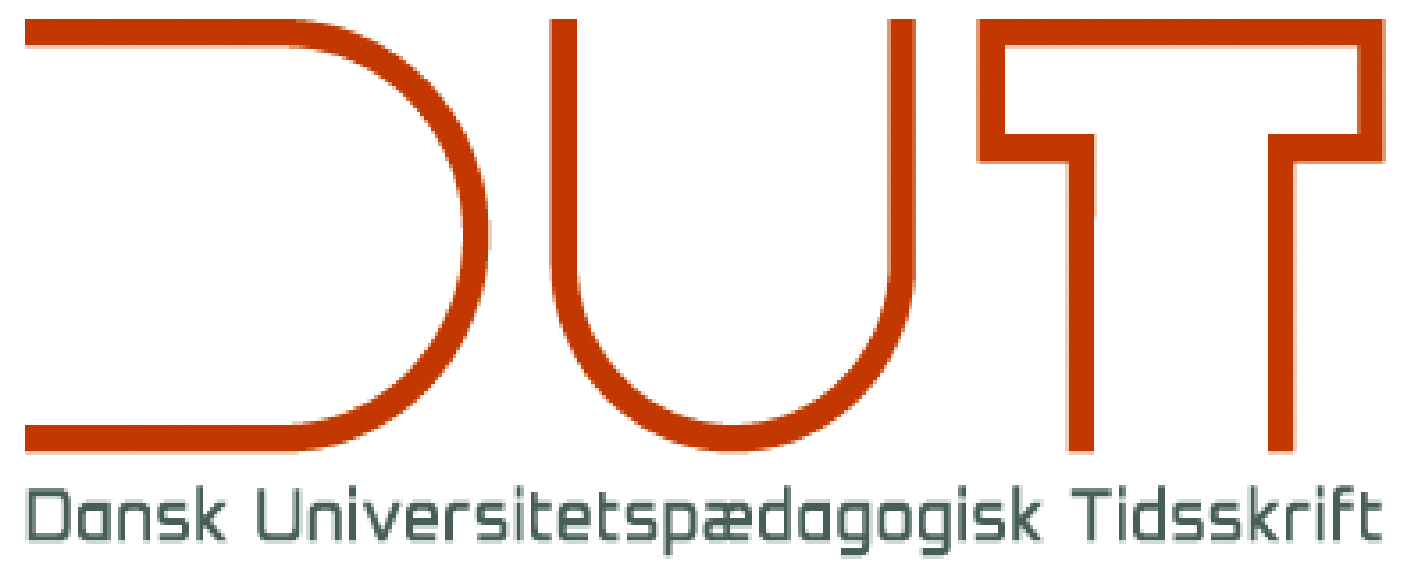

Tema

Nye perspektiver på evalueringsformer i universitetspædagogik

Årgang 12 nr. 23 / 2017

Titel

En usleben diamant" - Video i udviklingen af masterstuderendes kritiske refleksion

Forfatter

Sidetal

Helle Merete Nordentoft og Mads Emil Guldmann Jensen

$71-86$

Udgivet af

Dansk Universitetspædagogisk Netværk, DUN

URL

> http://dun-net.dk/

Betingelser for brug af denne artikel

(c) Copyright
Denne artikel er omfattet af ophavsretsloven, og der må citeres fra den. Følgende betingelser skal dog være opfyldt:

- Citatet skal være i overensstemmelse med "god skik"

- Der må kun citeres „i det omfang, som betinges af formålet“

- Ophavsmanden til teksten skal krediteres, og kilden skal angives ift. ovenstående bibliografiske oplysninger.

DUT og artiklens forfatter 


\section{"En usleben diamant": Video i udviklingen af masterstuderendes kritiske refleksivitet}

Helle Merete Nordentoft, lektor, ph.d., Institut for Uddannelse og Paedagogik, Aarhus Universitet

Mads Emil Guldmann Jensen, cand.mag., Institut for Uddannelse og Poedagogik, Aarhus Universitet

\section{Videnskabelig artikel, fagfællebedømt}

I denne artikel udforsker vi, hvordan video bidrager til at udvikle masterstuderendes kritisk refleksive blik på egen vejledningspraksis. Omdrejningspunktet er det didaktiske og dialogiske arbejde med video på modul 3, Master i Vejledning, DPU. Artiklen er baseret på de studerendes individuelle og parvise refleksioner i løbet af modulet som et led i at styrke deres kritiske refleksivitet og laring. Det kan vare sårbart for studerende at eksponere egen praksis på video, men analyserne peger på, at det dialogiske peer-arbejde med video fungerer som øjenåbner, der udfordrer normative vejledningsteoretiske forforståelser af, hvad der bør ske i vejledningsrummet. Det didaktiske arbejde med video har således potentiale ift. at give studerende et akademisk funderet og nuanceret blik på deres professionelle handlerum i praksis. Video bringer praksis ind i det akademiske loeringsrum og initierer kritisk refleksive og videnskabsteoretisk funderede dialoger om, hvordan man som professionel både skaber og er medskabende i vejledningssamtalens dynamik.

\section{Indledning}

Evnen til at reflektere og forholde sig teoretisk og kritisk til et fagligt stof er en central kompetence i en akademisk kontekst. Dog peger flere uddannelsesforskere på, at studerende kan have svært ved at tilegne sig et kritisk refleksivt blik, og at de ofte er mere deskriptive end kritiske i deres refleksioner (Ryan, 2013; Tutticci, Ryan, Coyer, \& Lewis, 2017). Coward (2011) går så langt som til at sige, at refleksionsbegrebet er blevet udvandet, og at der er opstået en form for "reflection fatigue", hvor en forsimplet opfattelse af refleksionsbegrebet synes at være svaret på al læring. I denne sammenhæng ser hun, at de mange strukturerede refleksionsmodeller, som er udviklet med afsæt i fx Schöns eller Bouds refleksionsteorier (Boud \& Molloy, 2013; Schön, 1994), hæmmer en kritisk tænkning og refleksivitet, som netop er karakteriseret ved et blik for kontekstuel kompleksitet, magtforhold og de dilemmaer og modsætninger, der kan være indlejret i konkrete episoder fra praksis (Bassot, 2014; Cunliffe, 2002, 2004b; Phillips, Kristiansen, Vehviläinen, \& Gunnarsson, 2012). Nyere forskning peger på, hvordan arbejdet med video kan være en kilde til dybere læring i en universitetspædagogisk kontekst (Buhl, 2011; Mitra, Lewin-Jones, Barrett, \& 
Williamson, 2010; Rasi \& Poikela, 2016), og ift. udvikling af en kritisk refleksiv bevidsthed hos professionelle, forskere og i arbejdslivet (Bjørndal, 2012; Carroll, Ledema, \& Kerridge, 2008; ledema, 2003; Jones \& McNamara, 2004; Taylor, 2011). I deres forskning viser Wichmann-Hansen, Thomsen, \& Nordentoft (2015) fx, hvordan video er med til at give vejledere af masterstuderende blik for udfordringer i subtile kropslige og interaktionelle dynamikker. Og ifølge Mitra et al. tilføjer video kontekstuelle og emotionelle informationer, som danner afsæt for mere nuancerede og kontekstsensitive refleksioner hos de studerende i en akademisk kontekst (Mitra et al., 2010).

På modul 3: "Vejledning i praksis" på Master i Vejledning, DPU, er vi inspireret af denne forskning. Siden 2007 har arbejdet med egne videooptagelser været en integreret del af undervisningen og vejledningen. I vores didaktiske og dialogiske tilgang til læringen på modulet ønsker vi at facilitere en proces, hvor de studerende udvikler et nuanceret og analytisk akademisk funderet sprog, som de kan omsætte i en kritisk refleksiv tilgang til deres vejledningspraksis. I denne artikel søger vi således at besvare forskningsspørgsmålet: Hvordan bidrager det didaktiske arbejde med video til at udvikle masterstuderendes kritiske refleksivitet?

Artiklen falder i 4 dele: I den første del ser vi på aktuel forskning ift. video, læring og kritisk refleksivitet, før vi i den anden del uddyber den didaktiske tilrettelæggelse med at inddrage video i undervisningen på modulet. Dernæst redegør vi for det empiriske afsæt i artiklen efterfulgt af vores analytiske fund. Til slut sammenfatter vi artiklens centrale pointer i lyset af den eksisterende forskning - herunder, hvordan en akademisk efteruddannelse med video udvikler de studerendes analytiske kompetencer, samt hvordan video kan sætte spor ikke kun i den studerendes, men også i den universitetspædagogiske praksis.

\section{Video, kritisk refleksivitet og læring}

I gennemgangen af den eksisterende forskning, hvor video indgår, er det tydeligt, at video kan forbinde centrale elementer i en læringsproces. Mitra et al. peger fx på, at arbejdet med video befordrer de studerendes evne til at koble tidligere og ny viden med hinanden (Mitra et al., 2010), og ifølge Rasi \& Poikela (2016) kan video bygge bro mellem uddannelse og "authentic work" og trigge diskussioner om "virkelige problemer" og "tacit beliefs". Jones \& McNamara viser bl.a., hvordan video kan skabe et kritisk blik på "taken for granted" antagelser og forforståelser (Jones \& McNamara, 2004). En forklaring på dette kan ifølge Buhl (2011) være, at arbejdet med en videooptagelse skaber "a dual space of experience", som giver den studerende mulighed for at skabe en analytisk distance til sin egen praksis og desuden arbejde med de kropslige erfaringer og nye observationer, som stimuleres i arbejdet med video. I denne sammenhæng argumenterer Caroll et al. (2009) for, at video-etnografiske metoder har potentiale for at kvalificere både praktikeres og forskeres forståelse af den 
stigende kompleksitet, som institutionelle praksisser er karakteriseret af. ledema (2003) beskriver, hvordan video netop kan belyse, artikulere og skabe en kritisk refleksiv bevidsthed omkring normative og affektive forhold i en given kontekst.

Bjørndal (2012) har interviewet vejledere, som har arbejdet med video i deres praksis, og han viser, hvordan arbejdet med video kan være ambivalent, da det er karakteriseret ved en pendulering mellem at være dybt fascineret og at føle et stort ubehag i mødet med sig selv. Hans fund underbygger de tendenser, som Perlberg beskriver i sin forskning om undervisere og deres "self-confrontation" gennem video i en højere uddannelseskontekst (Perlberg, 1983). Vejlederne i Bjørndals forskning understreger dog, at gevinsten ved at arbejde med video overstiger ubehaget. Taylor (2011) og Jones \& McNamara (2004) viser med deres forskning det frugtbare i, at arbejdet med video foregår i grupper, da det er med til at overvinde de følelsesmæssige barrierer i mødet med sig selv på video.

Nyere forskning indenfor universitetspædagogik supplerer ovennævnte tendenser og peger på, at en mere multimodal tilgang til undervisningen på universitetet rummer et stort potentiale ift. at motivere de studerende i deres læringsproces. Arbejdet med at producere faglige videoer kan ændre de studerendes position fra at være passive modtagere til aktive producenter i en læringskontekst. Dette positionsskift øger deres positive "academic emotions" og giver dem energi og motivation til at udføre det akademiske arbejde (Pirhonen \& Rasi, 2016; Rasi \& Poikela, 2016). Endvidere får de studerende en række transfer-bare og praksisrettede kompetencer med på vejen - af både teknisk og menneskelig karakter. Fx peger mange forskere på, at de studerendes samarbejdsprocesser omkring både produktion og refleksion over deres produkt styrker deres samarbejdsevner og blik for diversitet (Amador, 2017; Taylor, 2011; Thomas \& Marks, 2014).

Forskningen viser således, at anvendelsen af video rummer mange didaktiske muligheder. Der mangler dog viden om, hvordan videooptagelser af studerendes egen praksis bidrager til at udvikle deres kritiske refleksivitet i en akademisk masteruddannelseskontekst. I forskningen indtil nu har det primært været underviseres og vejlederes egne praksissituationer, som har været omdrejningspunktet. I forhold til at belyse de studerendes perspektiv i den universitetspædagogiske forskning er der mere fokus på læringsudbytte end på kritisk refleksivitet - og de studerende arbejder ikke med videooptagelser af egen praksis. Enten arbejder de med egen producerede faglige videoer (Pirhonen \& Rasi, 2016), eller også arbejder de med simulationsspil, som de selv indgår i, og som er optaget på video (Thomas \& Marks, 2014; Tutticci et al., 2017). Således supplerer denne artikel Bjørndals forskning (Bjørndal, 2012), men han har interviewet vejledere og ikke studerende, som befinder sig i en akademisk kontekst. 


\section{Pædagogiske overvejelser i arbejdet med video på modulet}

På masteruddannelsen arbejder vi med et sociokulturelt og dialogisk perspektiv på læring, hvilket betyder, at vi ser læring som et dialogisk, relationelt og kontekstuelt fænomen, der er betinget af de studerendes aktive deltagelse (Bakhtin, 1981; Lave \& Wenger, 1991). Som professionelle i egen praksis må de studerende navigere i en hverdag, som er kompleks, og som kræver, at de kan forholde sig analytisk til og prioritere de mange behov, som ofte er til stede i en travl og uforudsigelig hverdag (Nordentoft, 2015; Nordentoft, \& Olesen, 2014a og Nordentoft, \& Olesen, 2014b). En kritisk refleksivitet fordrer et blik for den kontekstuelle kompleksitet og de mange dilemmaer og modsætninger, der er indlejret i konkrete episoder fra praksis (Bassot, 2014; Cunliffe, 2002, 2004b; Phillips, Kristiansen, Vehviläinen, \& Gunnarsson, 2012). Denne kompleksitet bliver på masteruddannelsen funderet i en socialkonstruktionistisk forståelse, hvilket åbner op for flere måder at forstå den dialogiske dynamik i en vejledningssamtale på - og heraf åbner for flere måder at kommunikere på. Med andre ord signalerer bevægelsen et skift fra et blik på den anden til et blik på sig selv i samspil med den anden. Dette blik inviterer til en kritisk overvejelse omkring betydningen af egen magtposition og normativt funderede forforståelser, erfaringer og værdier ift., hvordan den professionelle vurderer hhv. god/dårlig vejledningspraksis, og desuden refleksioner over, hvordan forforståelser er indlejret i diskursive forståelser af, hvad der anses for den rette måde at handle på i en konkret kontekst (Phillips et al., 2012b). Arbejdet med video kan således bidrage til at kvalificere et centralt forskningsfokus ift. masteruddannelser, nemlig hvordan de studerende kan bygge bro mellem teori og praksis, og hvordan video som pædagogisk metode kan medvirke til, at de studerende tilegner sig en akademisk dannelse gennem deres analytiske bevidsthed (Stegager, 2016; Aarkrog, 2008).

Afsættet for undervisningen, vejledning og eksamen er de studerendes arbejde med en video fra egen vejledningspraksis ${ }^{1}$. De masterstuderende kommer fra hele Danmark og arbejder professionelt med vejledning indenfor et bredt spektrum af offentlige og private institutioner - såsom studievalg, ungdommens uddannelsesvejledning, PPR, sygehuse, fængsler osv. Masterstuderende adskiller sig fra kandidatstuderende i kraft af deres alder (de studerende, som indgår i denne artikel, er i gennemsnit 46 år), deres erhvervserfaring, og for et flertal af de masterstuderende er det nogle år siden, de sidst har befundet sig i en akademisk kontekst. Den akademiske verden og det akademiske sprog er for mange masterstuderende nyt land. Endvidere er uddannelsen en betalingsuddannelse, og majoriteten af de studerende er

\footnotetext{
${ }^{1}$ Fra Studieordningen for Master i Vejledning: https://eddiprod.au.dk/EDDI/webservices/DokOrdningService.cfc?method=visGodkendtOrdning\&dokOrdn ingId=2042\&sprog=da
} 
sendt af sted af deres arbejde, som både har bevilget og betalt uddannelsen. Man kan derfor sige, at der er noget på spil for denne gruppe af studerende ift. at gøre det godt på uddannelsen, hvilket betyder, at det kan opleves som udfordrende og sårbart både at skulle optage en af sine egne vejledningssamtale og præstere et distanceret, akademisk funderet og kritisk refleksivt blik på sig selv som professionel vejleder (Bjørndal, 2012; Perlberg, 1983; Schmid, 2011). Derfor arbejder vi med at skabe en tryg atmosfære med en tydelig rammesætning og progression, som bygger på fire principper:

1. I vejledningen arbejder vi med Kollektiv Akademisk Vejledning (Nordentoft, Mariager-Anderson \& Smedegaard, 2016; Nordentoft, Thomsen, \& Wichmann-Hansen, 2013; Thomsen,\& Nordentoft, 2012), som bygger på 3 møder mellem 4-5 forskellige projekter i en vejledningsgruppe. Faciliteringen af vejledningen er inspireret af en Bakhtinsk forståelse af dialog (Bakhtin, 1981). Konkret betyder det, at vi anerkender og ser forskellighed som en styrke og drivkraft i læringsprocessen, da det er vores tese, at der skabes grobund for kritisk refleksivitet, forandring og læring i mødet mellem forskellige standpunkter, meningsuniverser og værdipositioner (Nordentoft \& Olesen, 214b; Phillips, 2011, s. 203; Skagen 2003). I undervisning og vejledning er peerdialoger og inddragelse af tidligere studerende vigtige elementer. Den udsathed og magtforskydning, som de studerende kan opleve, når de skal optage, vise og tale om deres video-sekvenser fra egen praksis, kan forebygges, når de ser, at deres medstuderende har det på samme måde, og desuden hører tidligere studerende berette om deres proces med at overvinde deres usikkerhed og ser deres video.

2. Endvidere søger vi at frisætte de studerende fra, hvordan man bør handle i konkrete situationer. I stedet beder vi dem være nysgerrige på, hvad der sker i samtalen - og hvorfor - gennem at have øje for tilsyneladende små og uvæsentlige detaljer og deres effekt. Med andre ord se på samspillet mellem vejlederen og den vejledte og hvilken effekt det, som vejlederen gør, har på den vejledte.

3. Endelig anbefaler vi den studerende at omtale sig selv som "vejlederen" og ikke "jeg" for at styrke fokus på 'sagen' og ikke 'personen' og på denne måde skabe en analytisk distance til det, som er på spil i samtalen.

\section{Metode}

Det empiriske materiale, som danner grundlaget for denne artikel, er indsamlet løbende gennem efterårssemesteret 2016 på modul 3 i et udviklingsprojekt, som vi kalder for "Spor i Praksis" (SIP). For at kvalificere udviklingen af de studerendes sprog og refleksivitet i en synergi mellem det akademiske pensum og de studerendes erfa- 
ringspraksis afsætter vi 1 time 3 gange på et modul til gruppe- eller parvise dialoger i undervisningen og beder de studerende optage deres refleksioner på deres iPhones og sende dem til os. Desuden følger vi fire studerende gennem hele masteruddannelsen gennem deres parvise refleksioner, iPhone-refleksioner og individuelle skriftlige refleksioner (pr. mail) om de tanker, som undervisningen sætter i gang ift. deres praksis. I introduktionen til refleksionerne inviterer vi de studerende til at tale sammen om, hvordan de oplever, at arbejdet med video giver mening i deres praksis. Derefter foregår refleksionerne uden indblanding fra underviseren.

I lyset af vores teoretiske og epistemologiske tilgang til læring, hvor vi ser læring som kontekstuelt og relationelt funderet, har vi valgt ikke at lave interviews, men alene bygge analysen på de studerendes refleksioner - med hinanden og individuelt i umiddelbar tilknytning til undervisningen på modulet. Analyserne bygger derfor på de studerendes parvise refleksioner i 2 ud af de 3 SIP-sessioner, som fandt sted på modul 3 som en del af undervisningen. 14 ud af 22 studerende har lavet optagelser, som indgår i vores undersøgelse - dvs. i alt 7 par-refleksioner (106 min). Desuden inddrager vi 14 individuelle skriftlige refleksioner fra de 4 studerende, som vi følger $\mathrm{i}$ SIP, og 2 individuelle refleksioner, som vi har modtaget på lyd (14 min.). Det er vores antagelse, at de studerendes samtaler med hinanden uden indblanding fra os (som både er forskere, vejledere og undervisere) udmønter sig i mere ligeværdige, måske mere ærlige og spontane kommentarer, end hvis vi var til stede. Af etiske grunde mener vi, at det må opleves som mindre konfronterende at tale med og blive udspurgt af en medstuderende fremfor en underviser/vejleder. Tidligere forskning understreger desuden det kollaborative potentiale, der ligger i arbejdet med video (Amador, 2017; Thomas \& Marks, 2014). Således får vi mulighed for at få indblik i, hvordan de studerende taler sammen, og hvordan deres dialog bidrager til udviklingen af en kritisk refleksivitet. Det tidsmæssige sammenfald mellem refleksionerne, undervisningen, vejledningen og deres arbejde med videoen ser vi som en styrke i empirien, da det giver et klart billede af, hvordan de studerende oplever læringsprocessen, mens de er midt i den.

Det er frivilligt at lave en SIP-lydoptagelse af sin par-refleksion. Med andre ord er informanterne i vores undersøgelse alene udvalgt, fordi de har lavet en lydoptagelse, og ikke fordi de kommer fra en bestemt vejledningskontekst eller har en bestemt baggrund. I fremtidig forskning kunne det være interessant at undersøge disse koblinger, men det ligger udenfor vores undersøgelse. Ligeledes kan det ses som et bias, at det ikke er alle studerende, som deltager i undersøgelsen. Inklusionskriterierne har således været 1) informanten har enten været en af de 4 studerende, som vi følger i SIP, eller 2) den studerende har deltaget i en par/gruppe-refleksion i SIP 2 og 3 på modul 3. Vi har endvidere modtaget informeret samtykke fra alle, som har bidraget til undersøgelsen, ligesom alle informanter fremstår anonyme i analyserne.

Analysestrategi 
Vores tilgang til analysen tager afsæt i tematisk analyse, som den er beskrevet af Braun og Clarke (Braun \& Clarke, 2006). Tematisk analyse er en induktiv analysestrategi i 6 faser, som identificerer, analyserer og rapporterer mønstre og tematikker i datamaterialet. Med afsæt i vores individuelle gennemgang af det transskriberede materiale har vi sammen udviklet 9 koder, hvor fokus især har været på, hvornår og hvordan de studerende er blevet "struck" (Cunliffe, 2002, s. 36) - med andre ord udtrykker overraskelse og/eller nysgerrighed (se figur 1). Ifølge Cunliffe danner en sådan "struckness" afsæt for at tænke kritisk refleksivt og lære nyt. Analyseprocessen er udmundet i 3 hovedtemaer, som vi behandler i analysen nedenfor.

1. Video som en åbenbaring af praksis

De studerende fortæller spontant om, at de bliver overraskede over det, som de ser. I dette tema uddyber vi, hvordan deres overraskelse kommer til udtryk.

2. Brud med egne forforståelser

Dette tema belyser, hvordan de studerendes forforståelser udfordres.

3. Blik for kompleksitet og handlemuligheder

Nogle studerende udviser en kritisk refleksivitet gennem at beskrive, hvordan kompleksiteten i en vejledningssamtale får betydning for vejlederens handlerum. Det handler det sidste tema om.

Figur 1: Oversigt over sammenhaeng mellem koder og temaer

\begin{tabular}{|l|l|}
\hline Tema & Koder \\
\hline $\begin{array}{l}\text { Video som en åbenbaring af } \\
\text { praksis }\end{array}$ & $\begin{array}{l}\text { Blik for nye elementer i samtalen, som overrasker } \\
\text { Ser noget nyt hver gang videoen ses }\end{array}$ \\
\hline Brud med egne forforståelser & $\begin{array}{l}\text { Gør ikke det, som jeg tror, jeg gør } \\
\text { Modsætning mellem vejleders og vejledtes reaktion } \\
\text { Overrasket over egen institutionelle målorientering }\end{array}$ \\
\hline $\begin{array}{l}\text { Blik for kompleksitet og handle- } \\
\text { muligheder }\end{array}$ & $\begin{array}{l}\text { Kan sætte ord på betydningen af kompleksitet } \\
\text { Blik for sig selv i samspil med den anden } \\
\text { Ser mange valg og handlemuligheder } \\
\text { Forholder sig til egen position som professionel i } \\
\text { den institutionelle kontekst }\end{array}$ \\
\hline
\end{tabular}

\section{Analyse}

De studerende oplever, at den tydelige ramme og struktur på modulet sammen med det dialogiske arbejde med video har befordret deres analytiske arbejde og skriveproces. I empirien står det desuden frem, at den klare afgrænsning af det analytiske objekt på modul 3 (den 3 minutters videooptagelse) har betydet, at et flertal af de 
studerende har fået en forståelse for, hvad empiri overhovedet er, og hvad det vil sige at lave en analyse i en akademisk kontekst (dette anser vi som en forudsætning for at kunne anlægge et kritisk refleksivt blik). Når det er sagt, udviser de studerende i varierende grad en kritisk refleksivitet, som vi nu vil gennemgå i de næste afsnit.

Video som en åbenbaring af praksis

Al empirien indikerer, at de studerende oplever at være kommet tættere på deres egen vejlederpraksis, og at de har udviklet nye kompetencer, de kan anvende i deres professionelle praksis. En studerende fortæller følgende om sit udbytte til en medstuderende i en af refleksionerne i SIP:

Jeg har fået meget mere bevidsthed omkring, hvad det er, jeg foretager mig $i$ min hverdag, i min vejledning, (...) det har voeret ret, det synes jeg har voret en ret vild oplevelse egentlig (...). Jeg blev overrasket over for eksempel mit kropssprog, hvor meget, hvor forskelligt det er fra samtale til samtale faktisk (...).

Oplevelsen er sandsynligvis vild for den studerende, fordi brugen af video har belyst en del af hendes praksis, som hun ikke var bevidst om. Kropssproget overrasker hende, og på trods af, at hun ikke kan fortælle sin samtalepartner, hvordan oplevelsen kommer til at påvirke hendes praksis i fremtiden, så er hun blevet ramt af noget, som har lært hende noget om hende selv og hendes væren i praksis. Ifølge Cunliffe (2004) rummer netop sådanne øjeblikke af ramthed - eller "struckness", som hun betegner det, kimen til læring. En anden studerende beskriver meget levende denne "ramthed" som en åbenbaring i en skriftlig individuel refleksion pr. mail - november 2016:

Videoklippet på 2,5 minutter og den korte transskription er en revolution eller åbenbaring i forhold til vejledningspraksis. Begge dele er som rå, matte diamanter, der langsomt bliver slebet og afslører deres voerdi. Hver gang et mikrostykke er slebet og bliver belyst, kaster det lyset tilbage i nye nuancer. Der er utrolige facetter $i$ de to små sten - hver gang du ser på dem, kommer der nye farver frem. Der kunne skrives metervis af opgaver om de to små brudstykker. Og det hele ville gøre mig klogere på praksis.

Citatet illustrerer den studerendes oplevelse af, hvor multifacetteret vejledning kan være, Med Buhls betegnelse "a dual space of experience" kan man her se, at videoen tydeligvis stimulerer nye observationer og kropslige erfaringer, som den studerende udtrykker meget malerisk i diamant-metaforen (Buhl, 2011). Åbenbaringen eller ramtheden, som den studerende oplever, kan fungere som en trædesten mod en mere kritisk refleksiv selvforståelse ift. den studerendes vejledningspraksis, hvilket vi udfolder i det nedenstående (Bassot, 2014; Cunliffe, 2004b; Rasi \& Poikela, 2016). 


\section{Brud med egne forforståelser}

En af de markante ting, de studerende oplever, når de analyserer på deres video, er et brud med deres forforståelser af, hvad der sker i en vejledningssamtale. En studerende beskriver dette på følgende måde i spørgeskemaundersøgelsen:

Filmen viser, hvad der sker "bag om ryggen" på os. Hvad vi er styret af uden at voere bevidste om det. Det har jeg så loert at identificere, analysere og udvikle pånu.

Udviklingen af den kritisk refleksive bevidsthed er karakteriseret af en "unsettling" dvs. en slags rystelse, som Cunliffe udtrykker det, af de grundlæggende antagelser, som de studerende har haft ift. deres virkelighedsopfattelse og den praksis, der ellers er så velkendt for dem (Cunliffe, 2004a). Den studerende bliver konfronteret med et modsætningsforhold mellem det, som de tror, de gør - og så det, som de faktisk gør (Nordentoft, 2015). En par-refleksion fra SIP illustrerer dette forstyrrende fænomen. I refleksionen taler parret om det at lytte:

A: Hvor meget lytter jeg? [...] Jeg er optaget i min tanke, af det, jeg gerne vil sige. Jeg springer over det med at høre efter, hvad der bliver sagt ... eller maerke ... altså hvordan den anden har det [...]. Det synes jeg da har sat nogle tanker $i$ gang hos mig, og det er jeg også blevet mere opmarksom på, efter jeg har lavet nogle videooptagelser.

B: Vidste du, at problemet var der inden, altså var det et opmoerksomhedspunkt for dig, før du startede...?

A: Nej ... Nej, det er noget, jeg ... faktisk, jeg blev opmaerksom på det, efter vi er startet på det her modul, og jeg tror, at det er videooptagelser, der ligesom ... Jeg er begyndt at kigge på mig selv, ikke kun ... altså også: Hvad er det, der foregår her og nu mellem mig og [den vejledte].

A: Man tror, at man er aktivt lyttende, og så siger de noget ...

B: Det er DINE tanker, der siger dét, ik'?

A: Jo, jo ...

I dialogen siger $A$, at hun tror, at hun lytter aktivt i sin vejledningssituation, men efter at hun har set sig selv på en videooptagelse, så oplever hun, at dette ikke altid er tilfældet. Videooptagelsen har skærpet hendes blik for sin egen ageren i praksis, og at hun ikke nødvendigvis lytter, som hun tror, hun gør. Vores analyse viser, at de studerende ikke kun får udfordret deres antagelser om, hvad de tror, de gør i deres vejledningssamtaler men også, hvordan den vejledte kan opfatte et fænomen anderledes, end de selv gør. En studerende siger fx ved en par-refleksion fra november 2016: "Det, jeg tror er en udstrakt hånd, det bliver opfattet på en helt anden måde".

Ligeledes går op for et flertal af de studerende, at de er meget mere styret af de in- 
stitutionelle mål i deres praksis, end de selv tror, de er (Nordentoft, \& Olesen, 2014b). I videooptagelserne bliver den institutionelle virkelighed, og hvordan denne påvirker vejledningssamtalen, meget nærværende - og ikke altid på en positiv måde. I en par-refleksion fra november 2016 siger en studerende:

Målet gør, at den der medmenneskelige kommunikation bliver overskygget (...). Og det der med at bilde sig ind - altså at det er en ligevoerdig samtale, at man kan møde dem der, hvor de er - det gør jeg ikke i mange situationer, for der er jo også et mål.

Hendes samtalepartner forstærker det kritiske blik på vejledning i en institutionel kontekst og siger:

Jeg tror ikke, at vejledning flytter meget $i$ virkeligheden - jeg er blevet meget kritisk overfor det - jeg vil begynde at måle på deres [vejledernes] resultater.

Med andre ord bliver spændingsfeltet og dilemmaet mellem at tilgodese henholdsvis systemet og den vejledte, som de studerende befinder sig i, meget nærværende for de studerende (Nordentoft \& Olesen, 2014a). Der åbnes op for, at den studerende bliver mere bevidst om de situerede magtforhold samt in- og eksklusionsprocesser, der befinder sig i den institutionelle vejledningssamtale (Phillips et al., 2012). Den pædagogiske øvelse i udviklingen af det kritiske refleksive blik er, at forstyrrelsen ikke bliver så stor, at de studerende oplever en afmagtsfølelse ift. at kunne påvirke den institutionelle virkelighed. Analyserne indikerer, at opdagelsen af spændingsfeltets betydning ikke kun kan betyde, at de studerende får øje for, hvad de kan påvirke, men også, hvad de ikke kan påvirke. I forhold til sidstnævnte er der flere af de studerende, som oplever, at denne erkendelse faktisk betyder, at de bliver mindre stressede. I et interview efter eksamen siger en studerende fx:

De ting, som jeg selv opdagede omkring min egen praksis, og at se det spoendingsfelt, jeg er i, det hjalp (...); faktisk blev jeg mere afslappet og mindre stresset over nogle ting, at så meget hjalp opgaven mig faktisk til at ligesom sige, at der er ting, jeg ikke kan gøre noget ved.

Nogle studerende udvikler og kan sætte ord på den forståelse, de får for betydningen af den kontekstuelle kompleksitet, der er indlejret i en institutionel vejledningssamtale. I det næste afsnit går vi tættere på, hvordan disse studerende viser tegn på en kritisk refleksiv bevidsthed.

Blik for kompleksitet og handlemuligheder

I en parvis dialog i SIP i november 2016 siger en studerende, at modulet har åbnet hendes øjne for:

... at der er simpelthen så mange muligheder, man kan gøre brug af i sådan en vejledning [...], det har voeret rigtigt interessant at se på, jamen, den kom- 
pleksitet, der egentlig er til stede. (...) Du kan jo ikke reagere på det hele, men det er jo interessant, hvad er det så, at man lige valger at reagere på, fordi jeg tager det jo ikke som et bevidst valg altid.

Handlerummet i praksis bliver tydeligvis mere situeret og nuanceret og er ikke længere blot bygget op omkring konkrete normative handlingsmodeller (Nordentoft, Thomsen, \& Wichmann-Hansen, 2013). Derimod oplever vi, at de studerendes udsagn viser, hvordan de ser deres vejledningspraksis funderet på en række komplekse valg- og handlemuligheder, som må tilpasses det, som den konkrete situation kalder på. En anden studerende fortæller i en parvis dialog i SIP i november 2016:

Det her modul, det har givet mig endnu mere nysgerrighed på at kigge på,hvad der egentlig sker (...), hvad er det egentlig for nogle valg, jeg har $i$ en vejledning (...), altså fordi det er jo valg (...), der er simpelthen så mange muligheder, man kan gøre brug af i sådan en vejledning.

I takt med forståelsen af, hvor mange valgmuligheder der kan være i en samtale, flyttes den studerendes fokus fra et blik på den anden til et blik på sig selv i samspil med den anden - et blik, som netop karakteriserer en kritisk refleksivitet. I samme par-dialog som ovenfor siger den studerende også:

Jeg ser det jo som, hvis vejledningen kører godt, så er jeg jo forhåbentlig medvirkende til, at den kører godt, men hvis den kører dårligt, så er jeg jo absolut også en del af det (...), og derfor synes jeg, at det er rigtigt vigtigt, at hvis jeg nu maerker: Aj, det er slet ikke sådan, at det skal vaere - at jeg så egentlig ved, at så er det mig, der skal skabe, altså lave en forandring i denne her samtale.

Udsagnet viser, hvordan den studerende har øje for egen andel i vejledningssamtalens forløb - og er bevidst om sit professionelle ansvar for samtalens forløb.

Sammenfattende illustrerer de tre temaer fra vores empiriske materiale en kronologisk bevægelse i den analytiske læreproces: Først oplever de studerende at blive overraskede/rystede, og så udfordres deres forforståelser. Mod slutningen af modulet har nogle af de studerende fået øje for den kompleksitet, som vejledningssamtalen rummer, og kan identificere nye handlerum i samtalen.

\section{Perspektiverende konklusion}

Tidligere forskning tager primært afsæt i den pædagogiske effekt af konstruerede faglige eller simulerede videoer fra en vejleder/undervisers synsvinkel og beskriver i en ofte meget overordnet form, hvordan de studerendes læring og kritiske refleksivitet styrkes. Til forskel fra denne forskning illustrerer vores fund på konkret vis, hvordan den kritiske refleksivitet næres i de studerendes situerede par-vise dialoger. Det er derfor et analytisk fund, at arbejdet med egne videoproduktioner og det 'at have noget på spil' ift. egen praksis og professionalitet kickstarter udviklingen af de ma- 
sterstuderendes kritiske refleksivitet. I analyserne ses det, hvordan de i forskellig grad får forstyrret deres forforståelser af, hvad de tror, der er på spil i vejledningssamtalen. Deres nysgerrighed vækkes, og de bliver optaget af, hvad der sker på den anden side af bordet - hos den vejledte. Et centralt forskningsbidrag er således at vise, hvordan det didaktiske arbejde med video i løbet af modulet har styrket de studerendes analytiske sprog og kritiske refleksivitet ift. egen praksis - en erkendelse, som nuancerer og udvider deres professionelle handlerum.

Nogle vil måske spørge, om ikke det kan være grænseoverskridende at optage en vejledningssamtale - ikke kun for den studerende, men også for den vejledte. Vores erfaring er det modsatte. Det er de færreste vejledte, som siger nej til at blive optaget i en god sags tjeneste. Faktisk vil vi sætte spørgsmålstegn ved, om det ikke er uetisk ikke at give det vigtigste rum i den professionelle hverdag - nemlig samtalen et videoeftersyn (Nordentoft, 2015).

Indtil nu er der ikke nogen studerende, som er droppet ud af modulet, så vi tænker, at samarbejdet og dialogen med medstuderende bidrager til, at den enkelte studerende overvinder den usikkerhed, som præger starten af modulet. Vores empiri og erfaringer viser endvidere, at et fokus på "sagen", dvs. udviklingen af den faglige dialog fremfor et personligt fokus på den, som kommunikerer, kvalificerer de kritiske refleksioner. Den største udfordring i arbejdet med video kan være de tekniske udfordringer, som nogle studerende oplever. Men - i reglen hjælper deres børn dem med at håndtere den!

Afslutningsvis ser vi, at vores analytiske fund har implikationer både for undervisningen på universitetet og for praksis af særligt to årsager: For det første motiverer arbejdet med og dialogen om video de studerende i deres læreproces og kvalificerer desuden det analytiske håndværk, som en del masterstuderende ellers kan have udfordringer med at tilegne sig. Men videoproduktioner skaber ikke kun læring for dem, som er involveret i modulet. Gennem studenteroplæg fra tidligere studerende og deling af deres produktioner skabes der en åbenhed omkring det akademiskanalytiske arbejde, som virker stimulerende i læringsprocessen. For det andet kan video bygge bro mellem akademia og praksis. Videooptagelserne bringer praksis ind i læringsrummet, og samtidig kan de ofte svært tilgængelige videnskabsteoretiske antagelser, såsom betydningen af forholdet mellem forsker og empiri eller antagelser om virkelighedens konstruktion, blive håndterbare i det analytiske arbejde med video (Pirhonen \& Rasi, 2016; Rasi \& Poikela, 2016). Her kan et kritisk refleksivt blik på videoen bidrage til at synliggøre, hvordan man som aktør i verden både skaber og er medskabende ift. verdens fremtoning. Blikket giver med andre ord en forståelse for, at det er muligt at bevæge praksis gennem det at handle anderledes. En erkendelse, som rummer etiske og dannelsesmæssige implikationer for livet både indenog udenfor universitetets mure, da det kritisk refleksive blik kan betyde, at de studerende får øje for de situerede magtforhold og in- og eksklusionsprocesser, de er en 
del af og bidrager til. Video som pædagogisk metode kan således facilitere, at vejledere uddannes til ikke kun at være "critical thinkers", men også "moral practitioners" (Cunliffe, 2004b).

Helle Merete Nordentoft, lektor/Associate Professor, ph.d.-koordinator for Masteruddannelsen i Vejledning ved Institut for Uddannelse og Paedagogik, Aarhus Universitet. Forsker i vejledning indenfor det universitetspaedagogiske felt. I min forskning er jeg optaget af, hvordan teori/praksis-forhold kan integreres didaktisk, så det giver mening både for studerende og det videnskabelige miljø. Herunder hvordan video som paedagogisk metode kvalificerer parternes kritisk refleksive blik og dialog.

Mads Emil Guldmann Jensen, cand.mag. i paedagogik fra Københavns Universitet. Assistent tilknyttet projekterne Spor i Praksis og Kollektiv Akademisk Vejledning ved Institut for Uddannelse og Paedagogik, Aarhus Universitet.

\section{Litteratur}

Amador, J. M. (2017). Video simulations to develop preservice mathematics teachers' discourse practices. Technology, Pedagogy and Education, 1-14. doi:10.1080/1475939X.2017.1281156

Bakhtin, M. M. (1981). The Dialogic Imagination. Four Essays. Austin \& London: University of Texas Press.

Bassot, B. (2014). Enabling culturally sensitive career counseling through critically reflective practice: the role of reflective diaries in personal and professional development. In S. Trefgarne \& L. Walmsley (Eds.), Handbook of career development (pp. 453-464). New York: Springer.

Bjørndal, C. (2012). Veilederes møte med seg selv. Betydningen av videoopptak og transkripsjon som utviklingsredskap. In A. Ulvestad \& F. Kärki (Eds.), Flerstemt veiled-ning (pp. 335-355). Oslo: Gyldendal.

Boud, D., \& Molloy, E. (2013). Feedback in higher and professional education : understanding it and doing it well: Routledge.

Braun, V., \& Clarke, V. (2006). Using thematic analysis in psychology. Qualitative Reseach in Psychology, 3, 77-101.

Buhl, M. (2011). Multimodality: On video mediated counselling for educational purposes. Paper presented at the Vietnam Forum on Lifelong Learning: Building a Learning Society, Hanoi.

Caroll, K. (2009). Outsider, insider, alongsider: Examining reflexivity in hospital-based video research. International Journal of Multiple Research Approaches, 3(3), 246263. doi:10.5172/mra.3.3.246 
Carroll, K., Ledema, R., \& Kerridge, R. (2008). Reshaping ICU ward round practices using video. reflexive ethnography. Qualitative Health Research, 18(3), 380-390.

Coward, M. (2011). Does the use of reflective models restrict critical thinking and therefore learning in nurse education? What have we done? Nurse Education Today, 31(8), 883-886. doi:https://doi.org/10.1016/j.nedt.2011.01.012

Cunliffe, A. L. (2002). Reflexive Dialogical Practice. Management Learning, 33(1), 35-61.

Cunliffe, A. L. (2004a). From reflection to practical reflexivity: Experiental learning as lived experience. In M. Reynolds \& R. Vince (Eds.), Organizing Reflection (pp. 3046). Ashgate: Aldershot.

Cunliffe, A. L. (2004b). On becoming a critically reflexive practitioner. Journal of Management Education, 28(4), 407-426.

Nordentoft, H. M. (2015). Linedans på video. Vejlederforum, 8(4).

Nordentoft, H. M., Mariager-Anderson, K., \& Smedegaard, A. (2016). Kollektiv Akademisk Vejledning - en introduktion

Nordentoft, H. M., \& Olesen, B. R. (2014a). Fra hurtige vurderinger til grundige analyser. Sygeplejersken, 12, 84-88.

Nordentoft, H. M., \& Olesen, B. R. (2014b). Kommunikation i kontekst. København: Munksgaards Forlag.

Nordentoft, H. M., Thomsen, R., \& Wichmann-Hansen, G. (2013). Collective academic supervision: a model for participation and learning in higher education. Higher Education, 65(5), 581-593.

Thomsen, R., \& Nordentoft, H. M. (2012). Kollektiv Akademisk Vejledning - et bud på en ændret organisering af vejledningen på universitetet. Dansk Universitetspoedagogisk Tidsskrift, 7(12), 106 - 116.

Wichmann-Hansen, G., Thomsen, R., \& Nordentoft, H. M. (2015). Challenges in Collective Academic Supervision: supervisors' experiences from a Master Programme in Guidance and Counselling. Higher Education, 70, 19 - 33. doi:DOI 10.1007/s10734-014-9821-2

ledema, R. (2003). Multimodality, resemiotization: extending the analysis of discourse as a multi-semiotic practice. Visual Communication, 2, 29-57. doi:10.1177/1470357203002001751

Jones, L., \& McNamara, O. (2004). The possibilities and constraints of multimedia as a basis for critical reflection. Cambridge Journal of Education, 34(3), 279-296. doi:10.1080/0305764042000289929

Lave, J., \& Wenger, E. (1991). Situated learning, legitimate peripheral participation. New York: Cambridge University Press. 
Mitra, B., Lewin-Jones, J., Barrett, H., \& Williamson, S. (2010). The use of video to enable deep learning. Research in Post-Compulsory Education, 15(4), 405-414. doi:10.1080/13596748.2010.526802

Perlberg, A. (1983). When Professors Confront Themselves Towards a Theoretical Conceptualization of Video-Self-Confrontation in Higher Education. Higher Education, 12(6), 633-663.

Phillips, L. (2011). Med forskel som forandringskraft : en introduktion til dialogisk kommunikationsteori. In P. Almlund \& N. B. Andersen (Eds.), Fra metateori til kommunikaiton (pp. 152-183). København: Hans Reitzels Forlag.

Phillips, L., Kristiansen, M., Vehviläinen, M., \& Gunnarsson, E. (2012). Tackling the Tensions of Dialogue and Participation: Reflexive Strategies for Collaborative Research. In L. Phillips, M. Kristiansen, M. Vehviläinen, \& E. Gunnarsson (Eds.), Knowledge and Power in Collaborative Research: A Reflexive Approach (pp. 1-21). New York: Routledge.

Pirhonen, J., \& Rasi, P. M. (2016). Student-generated instructional videos facilitate learning through positive emotions. Journal of Biological Education, 1-13. doi:10.1080/00219266.2016.1200647

Rasi, P. M., \& Poikela, S. (2016). A Review of Video Triggers and Video Production in Higher Education and Continuing Education PBL Settings. Interdisciplinary Journal of Problem-Based Learning, 10(1). doi:10.7771/1541-5015.1609

Ryan, M. (2013). The pedagogical balancing act: teaching reflection in higher education. Teaching in Higher Education, 18(2), 144-155. doi:10.1080/13562517.2012.694104

Schmid, E. C. (2011). Video-stimulated reflection as a professional development tool in interactive whiteboard research. ReCALL, 23(3), 252-270.

Schön, A. (1994). The Reflective Practitioner. USA: Massachusetts Institute of Technology.

Skagen, K. (2003). Vejledningssamtaler i et Bakhtinsk perspektiv. In O. Dysthe (Ed.), Dialog, samspil og loering (pp. 197-214). Århus: Forlaget Klim.

Stegager, N. (2016). Kvalitet i danske masteruddannelser - Et spørgsmål om kompetenceudvikling eller akademisk dannelse? Dansk Universitetspoedagogisk Tidsskrift, 11(20), 113-121.

Taylor, C. A. (2011). More than meets the eye: the use of videonarratives to facilitate doctoral students' reflexivity on their doctoral journeys. Studies in Higher Education, 36(4), 441-458. doi:10.1080/03075071003714115 
Thomas, K., A., \& Marks, L. (2014). Action!: Student-Generated Videos in Social Work Education. Journal of Technology in Human Services, 32(4), 254-274.

doi:10.1080/15228835.2014.922912

Thomsen, R., \& Nordentoft, H. M. (2012). Kollektiv Akademisk Vejledning - et bud på en ændret organisering af vejledningen på universitetet. Dansk Universitetspoedagogisk Tidsskrift, 7(12), 106 - 116.

Tutticci, N., Ryan, m., Coyer, F., \& Lewis, P. A. (2017). Collaborative facilitation of debrief after high-fidelity simulation and its implications for reflective thinking: student experiences. Studies in Higher Education, 1-14. doi:10.1080/03075079.2017.1281238

Aarkrog, V. (2008). Masterstuderendes kobling af teori og praksis. Inspiration til en videreudvikling af masterpædagogikken. Dansk Universitetspoedagogisk Tidsskrift, 5, 33-38. 